\title{
VYBRANÉ ENVIRONMENTÁLNE SÚVISLOSTI ZMIEN HISTORICKEJ LAZNÍCKEJ KRAJINY (NA PRÍKLADE OBCE HRUŠOV OKRES VELKÝ KRTÍŚ)
}

\author{
Ján Hanušin, Ján Lacika* \\ * Geografický ústav SAV, Štefánikova 49, 81473 Bratislava, \\ hanusin@savba.sk, lacika@savba.sk
}

\begin{abstract}
Selected environmental contexts of changes in the historical landscape with scattered settlement (the example of the village of Hrušov, Vel'ký Krtíš district)

Using the example of the cadastral territory of the Hrušov village, we identified and interpreted changes in the land cover (LC), land diversity (LD) and road network in 1950 and 2010 in relation to the scattered settlement system. The LC and LD changes were identified on three spatially different levels: in the whole cadastral area, in the natural landscape units and in 20 circular areas. Landscape diversity was evaluated by using the Shannon diversity index. The scattered settlements system, by its origin and unique functioning in Slovakia, conditioned some anomalies in LC development which are typical for marginal regions and/or areas with such a type of settlements - delayed, incomplete or no collectivization of agriculture. On the other hand, the retreat and partial extinction of scattered settlements resulted in changes in LC, whose intensity exceeded the values typical in the wider region.
\end{abstract}

Key words: cultural landscape changes, land cover changes, landscape diversity changes, local road network, Shannon diversity index, scattered settlement, Hrušov, Vel'ký Krtíš district

\section{ÚVOD}

Rozptýlené (roztratené, kopaničiarske a laznícke) osídlenie je výrazným a osobitým fenoménom slovenských Karpát. Charakteristickým osídlením, svojráznymi historickými krajinnými štruktúrami i svojbytnou stavebnou kultúrou vpísalo nezmazatel'né stopy do karpatskej krajiny a vytvorilo jedinečné prejavy hmotného aj nehmotného dedičstva a neopakovatel'ného genia loci. Napriek tomu, ako uvádza Huba (1989), že tento druh osídlenia znamenal len dosídl'ovanie dovtedajšej anekumény v odl'ahlých a málo vhodných častiach katastrov a predstavoval do istej miery vždy extrémny a núdzový sídelný prejav, nemožno rozptýlené osídlenie v rámci Slovenska vnímat' ako okrajový jav. V roku 1961 bolo na Slovensku v 166 obciach temer 2900 kopaníc, v ktorých žilo asi 140 tisíc obyvatel'ov. Pät' oblastí rozptýleného osídlenia zaberalo $4640 \mathrm{~km}^{2}$, teda temer desatinu rozlohy Slovenska (Verešík 1974). Približne rovnaký počet obyvatel’ov žil na kopaniciach aj v roku 1991 (Spišiak 1998). Laznícke osídlenie v hontianskej obci Hrušov (okres Vel'ký Krtíš), predmet našej štúdie (obr. 1), je vizuálne i funkčne podobné iným areálom lazníckeho osídlenia na Krupinskej planine, geneticky je však odlišné. Na rozdiel od väčšiny ostatných oblastí s rozptýleným osídlením, ktoré vznikli osídl'ovaním „zvonka”, teda prišelcami z iných regiónov, hrušovské lazy vznikli osídl’ovaním „Zvnútra”, boli založené miestnymi obyvatel'mi. Ciel’om príspevku je na príklade Hrušova identifikovat', porovnat' a interpretovat' vybrané environmentálne a spoločenské zmeny medzi rokmi 1950 a 2010 vo vzt'ahu k systému rozptýleného osídlenia. 


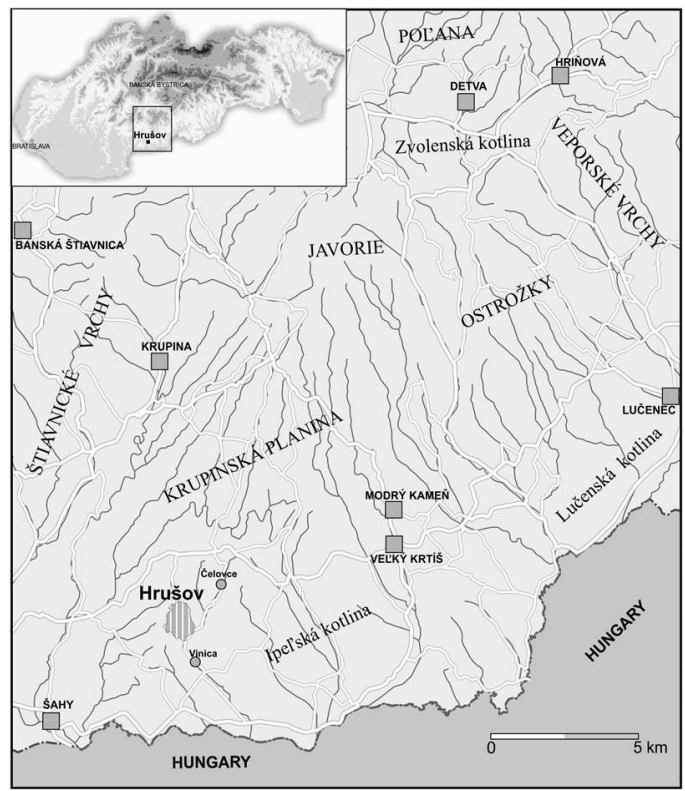

Obr. 1. Poloha študovaného územia

\section{PREHLAD ŠTUDOVANEJ PROBLEMATIKY}

Prvé významnejšie práce zamerané na výskum rozptýleného osídlenia na Slovensku vznikli v prvej polovici 20. storočia. Napriek tomu, že tento druh výskumu má interdisciplinárny charakter, najviac štúdií vzniklo v rámci geografie a príbuzných vied. V prvej polovici minulého storočia to boli najmä ,klasické“ diela Martinku (1927), Janšáka (1929), Hromádku (1943) a Feketeho (1947), ktoré položili základ výskumu tohto fenoménu u nás. V d’alšom období sa problematikou rozptýleného osídlenia z geografického aspektu zaoberali napr. Verešík (1974), Lukniš (1980), Huba (1989, 1990 a 1997), Lauko (1985), Spišiak (1998) a Omasta (2011). Komplexný prehl'ad o histórii výskumu regiónov s rozptýleným územím z rôznych aspektov s dôrazom na klasifikáciu a členenie kopaničiarskych oblastí ponúka Petrovič (2005). Z negeovedných disciplín sa problematike rozptýleného osídlenia venovali napr. Nahálka et al. (1966), Śvecová (1979, 1980, 1984 a 1988), Horváth (1980), Prelovská (1987), Priečko (2003 a 2015) a iní.

Obec Hrušov a jej katastrálne územie je populárnou témou najmä etnologických a v menšej miere aj prírodovedných výskumov. Máloktorá obec podobnej vel'kosti na Slovensku má takú dôkladne spracovanú históriu hmotnej i nehmotnej kultúry. Najrozsiahlejším, 6-zväzkovým príspevkom je edícia Tradičná l’udová kultúra obce Hrušov, z ktorej sú pre výskum zmien krajiny najprínosnejšími čast’ami Rol'níctvo v Hrušove (Brada et al. 2014) a Tradičné stavitel'stvo v Hrušove (Brada a Brloš 2013). Dvojrezidenčnost', v podstate hlavnú hybnú silu vzniku hrušovských lazov, si vo svojej štúdii všíma Botík (1980). Porovnanie zachovalosti historických krajinných štruktúr v Hriňovej a Hrušove prezentovala krajinno-ekologická štúdia Zrníkovej a Hrčkovej (2012). Problematike rozptýleného osídlenia širšieho hontianskeho lazníckeho regiónu primárne $\mathrm{z}$ etnologického pohl'adu sú venované práce Švecovej $(1979,1980,1984$ a 1988). 
Transformácia krajiny je svojím obsahom komplikovaný mnohorozmerný proces, spätnou väzbou prepojený s prírodnými a spoločenskými danost’ami príslušného územia. Vzhl'adom na svoju vnútornú heterogenitu a komplikovanost' nie je určenie stupňa transformácie krajiny vždy jednoduché a jednoznačné. Jedným z najrozšírenejších indikátorov transformácie krajiny, ktoré sme využili aj v našej štúdii, je hodnotenie zmien krajinnej pokrývky (land cover, LC). Podl'a Ot'ahel'a et al. (2004) krajinná pokrývka predstavuje zhmotnený priemet prírodných priestorových daností a využívania krajiny. Ucelený pohl'ad na historický vývoj a teoretické aspekty problematiky zmien krajinnej pokrývky a využitia krajiny na Slovensku spracovali napr. Feranec a Ot'ahel' (2009). Dalším významným indikátorom transformácie krajiny je zmena krajinnej diverzity (KD), ktorá je jednou z krajinných metrík. Členenie, terminológia a definície krajinných metrík nie je vždy jednotné, na čo upozornil už napr. Gustafson (1998). Krajinné metriky sa počítajú na úrovni indivídua (biologický druh a objekt), plôšky, mozaiky a napokon krajiny ako hierarchicky najvyššej a najkomplexnejšej jednotky. Ich členenie ponúkajú napr. Li a Reynolds (1993 in Gustafson 1998), McGarigal (2002) a Farina (2006). Spomínaní autori v zásade členia krajinné metriky na nepriestorové (angl. non-spatial metrics) a priestorové (angl. spatial metrics). Na výpočet KD sa používa viac typov krajinných indexov od jednoduchých, ako je napríklad index bohatosti plôšok (patch richness), až po relatívne zložitejšie, ako napr. Shannonov index krajinnej diverzity (SHDI) alebo Simpsonov index krajinnej diverzity. Hodnoty KD sa počítajú väčšinou pre menšie jednotky, umožňujúce hodnotit' priestorové rozloženie vel'kosti, resp. zmien KD. Často je to pravidelná štvorcová či hexagonálna siet' (u nás tento postup použili napr. Ot'ahel' et al. 2002 a 2004, Boltižiar 2007, Ivanová et al. 2012, Hanušin a Štefunková 2015) alebo prirodzené prírodné jednotky, napr. mikropovodia (Hreško et al. 2006).

Vývoj cestnej siete ako jeden z aspektov historického vývoja krajiny na území katastrálneho územia Hrušova bol prezentovaný v práci Bradu a Brloša (2013). Jej autori vychádzali z výskumu historických dokumentov vrátane historických kartografických podkladov, akými sú mapy z troch vojenských mapovaní monarchie a mapy vytvorené v rámci vojenského a pozemkového mapovania po rozpade Rakúsko-Uhorska.

\section{POUŽITÁ METODIKA}

Environmentálne zmeny v študovanom území sme analyzovali prostredníctvom zmien LC a KD, ktoré sme hodnotili na troch rôznych priestorových hierarchických úrovniach pre roky 1950 a 2010. Analýza priebehu a zmien lokálnej siete ciest slúžila ako doplňujúca charakteristika.

Pri vymedzovaní kategórií LC sme vol’ne vychádzali zo zaužívanej klasifikácie Corine Land Cover - CLC (Feranec a Ot'ahel' 1999) so zmenami, ktoré zohl'adnili miestne špecifiká, z ktorých za najdôležitejšie považujeme:

a) zalesňovanie a extenzifikáciu využívania pol'nohospodárskej krajiny, pre ktorú sú typické najmä prechodné, resp. kombinované kategórie LC s významným podielom sukcesie lesa a nelesnej drevinovej vegetácie (NDV). Ku kategórii lesy sme priradili aj areály kompaktnej NDV s rozlohou 0,5 ha a viac (remízky a pod.). Pri lúčnych areáloch a pri pol'nohospodárskych mozaikách sme využili ako kritérium vzájomného odlíšenia podiel NDV (do $20 \%$ a nad $20 \%$ ), ktorý vyjadruje intenzitu procesu sukcesie lesa; 
b) hustá siet' lazov a lokálnej cestnej siete, ktorá spája lazy s ústredím v Hrušove a lazy navzájom.

Najmenšia mapová jednotka zodpovedala areálu približne $450-500 \mathrm{~m}^{2}$. Vzhl'adom na to, že sme chceli podchytit' všetky areály lazov, najmenšiu mapovatel'nú jednotku sme pre túto kategóriu (zástavba na lazoch vrátane pridomových záhrad) nestanovili. Mapovali sme ich všetky, pričom do takto vymedzených areálov sme zahrnuli aj pridomové záhrady ako špecifickú bezprostrednú funkčnú súčast' lazníckeho osídlenia. Sledované obdobia (1950 a 2010) vyjadrujú stav LC v predkolektivizačnom období a v súčasnosti. Základnou databázou pre obdobie roku 1950 boli georeferencované listy historickej ortofotomapy Slovenska z roku $1950^{1}$. Databázou pre zhotovenie mapy LC za obdobie roku 2010 boli príslušné listy leteckej ortofotomapy z roku 2003, ktorá bola aktualizovaná na základe leteckých snímok z internetového mapového servera mapy CZ (2012). Pri hodnotení charakteru zmien LC sme sa - až na niektoré výnimky - pridržiavali typológie zmien LC v zmysle Feranec et al. (2002).

Hodnotenie zmien LC a KD sme robili na troch priestorovo odlišných úrovniach. Na celom katastrálnom území obce, na strednej úrovni v prírodných krajinných jednotkách a na 20 kruhových areáloch reprezentujúcich najnižšiu úroveň.

$\mathrm{Na}$ hodnotenie zmien LC a KD na strednej úrovni sme prírodnú krajinu rozčlenili do troch hierarchických zoskupení. Na najvyššej úrovni členenia prírodnej krajiny sú prírodné krajinné celky, zodpovedajúce dvom základným morfologickým makrotvarom - planine a úbočiam, ktoré sa na nižšej úrovni členia na prírodné krajinné typy $(\mathrm{PKT})$ - dva typy v rámci makrotvaru planín a sedem typov v rámci makrotvaru úbočí (tab. 1 a obr. 2). Individualizované PKT sme označili ako prírodné krajinné jednotky (PKJ), ktorých je spolu 21. V nasledujúcom texte používame príslušné označenie (PKT alebo $\mathrm{PKJ}$ ) s ohl'adom na kontext.

Tab. 1. Prírodné krajinné typy

\begin{tabular}{lcccc}
\hline Celok & Typ (PKT) & Kód & $\begin{array}{c}\text { Plocha } \\
\text { (ha) }\end{array}$ & $\begin{array}{c}\text { Podiel na } \\
\text { rozlohe (\%) }\end{array}$ \\
\hline planina & plošina & A1 & 526,42 & 22,6 \\
planina & plytká dolina & A2 & 127,57 & 5,5 \\
úboče & mierne členená zníženina & B1 & 483,49 & 20,7 \\
úboče & strmý dolinový svah & B2 & 694,21 & 29,6 \\
úboče & izolovaná elevácia & B3 & 276,46 & 12,0 \\
úboče & plochá rázsocha & B4 & 73,00 & 3,2 \\
úboče & dolinové dno & B5 & 76,30 & 3,3 \\
úboče & plytká dolina & B6 & 47,22 & 2,0 \\
úboče & členená dolina & B7 & 26,38 & 1,1 \\
\hline
\end{tabular}

\footnotetext{
${ }^{1}$ Historická ortofotomapa (C GEODIS SLOVAKIA, s.r.o., Historické LMS @ Topografický ústav Banská Bystrica, Ortofotomapa (C) EUROSENSE, s.r.o. a GEODIS SLOVAKIA, s.r.o., mapové podklady C Topografický ústav Banská Bystrica, (C) TU Zvolen.
} 


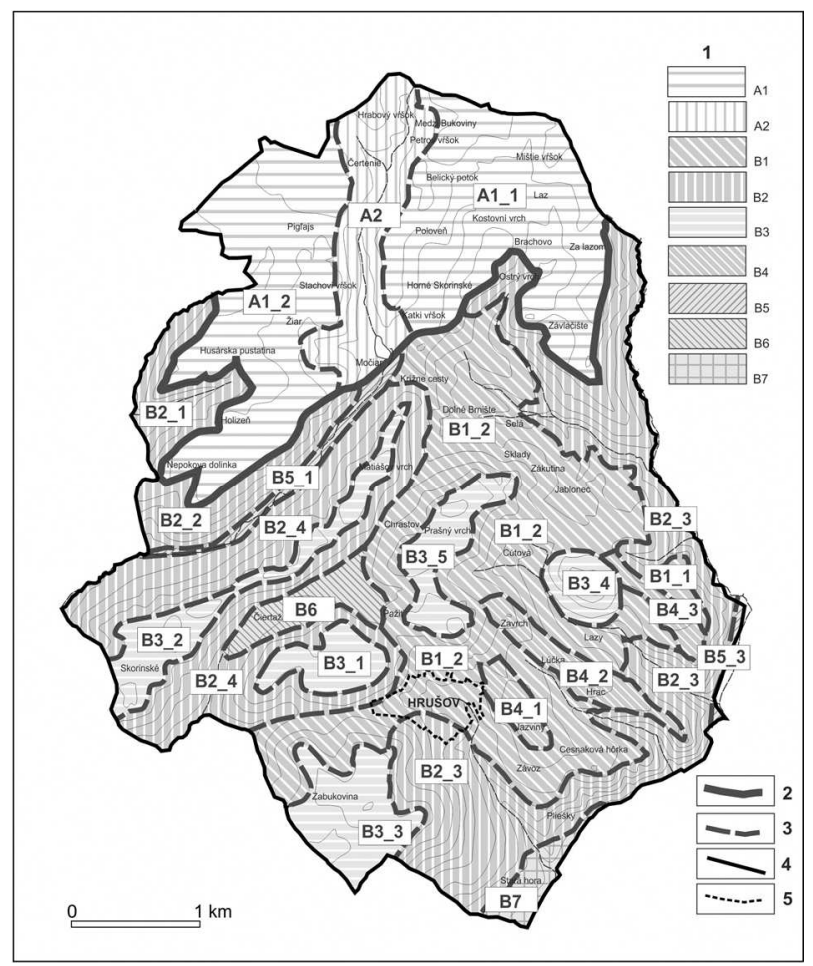

Obr. 2. Prírodné krajinné typy a jednotky

Legenda: 1 - prírodné krajinné typy, (pozri tab. 1), 2 - hranice prírodných krajinných celkov, 3 - hranice prírodných krajinných typov, 4 - hranica katastrálneho územia, 5 - hranica intravilánu obce.

Vychádzajúc z predpokladu, že v pohoriach, resp. v členitých krajinných celkoch všeobecne, je rozhodujúcim diferenciačným kritériom reliéf, hlavným kritériom vyčleňovania PKT boli geomorfologické vlastnosti územia. Vyčlenené PKT môžeme preto do vel'kej miery stotožnit' s morfotypmi.

Najnižšia priestorová úroveň, v ktorej sme hodnotili charakter a zmeny LC a $\mathrm{KD}$, boli kruhové areály vo vybraných lokalitách. Na tejto úrovni sme sa pokúsili zistit', či a akým spôsobom sa odlišovali zmeny v LC a KD v bezprostrednom zázemí lazov v porovnaní so zmenami na úrovni PKT/PKJ. Zázemie lazov sme vymedzili kružnicou s polomerom 200 metrov (čo zodpovedá ploche približne 12,5 ha) so stredom v centre zástavby príslušného lazu. Spolu sme lokalizovali 20 kruhových areálov, stred $12 \mathrm{z}$ nich sme vytýčili v strede lazov, zvyšných osem kruhových areálov sme pre porovnanie vytýčili tak, aby nezasahovali do zástavby, resp. zázemia lazov (obr. 3). Areály so stredom na lazoch sme označili ako areály so sídlom, v druhom prípade ako areály bez sídla. Areály sme rozmiestnili tak, aby bol v každom PKT aspoň jeden areál. Na vyhodnotenie zmien LC sme použili porovnanie percentuálneho podielu rozlohy vybraných kategórií LC na ploche kruhového areálu, charakterizujúcich najvýznamnejšie druhy zmien krajinnej pokrývky (lesy - zalesnenie, ornú pôdu a kategórie s vyjadrením podielu sukcesie reprezentu- 
júce extenzifikáciu, resp. intenzifikáciu krajiny z hladiska jej pol’nohospodárskeho využitia).

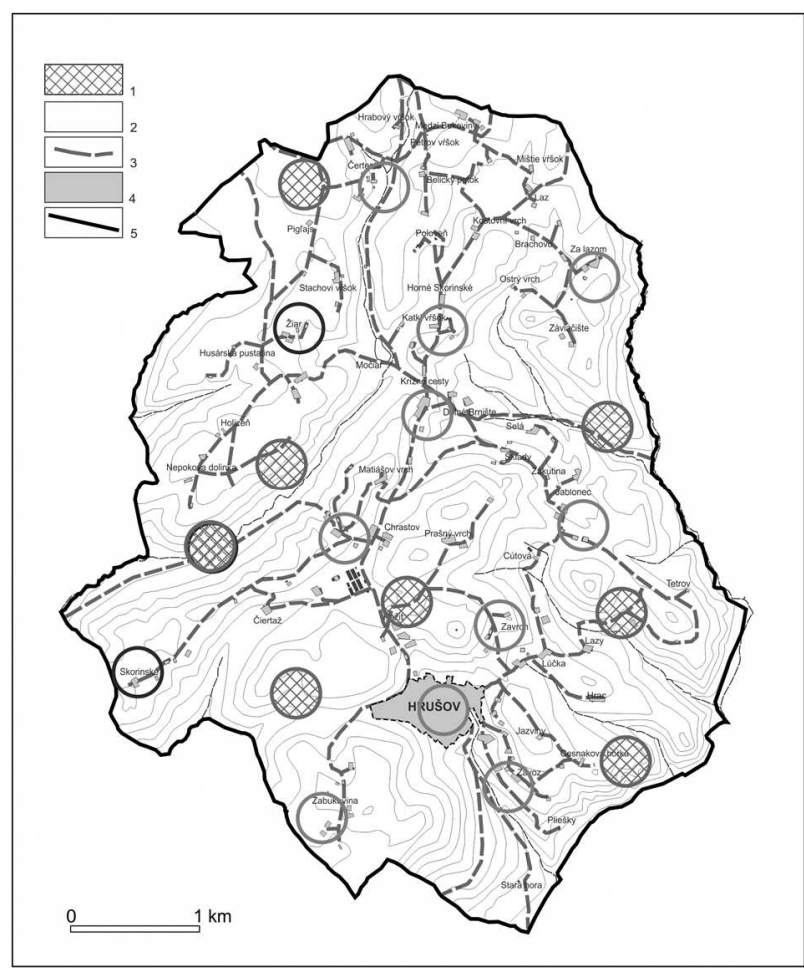

Obr. 3. Rozloženie analyzovaných kruhových areálov

Legenda: 1 - kruhové areály bez sídla, 2 - kruhové areály so sídlom, 3 - cesty, 4 - zastavaná plocha, 5 - hranica katastrálneho územia.

Výpočet KD a jej zmien sme robili pomocou Shannonovho indexu diverzity (SHDI, Shannon diversity index), niekedy aj Shannon-Weaverovho indexu, ktorý patrí k najčastejšie používaným metrikám krajinnej diverzity.

SHDI sa vypočíta podla vzt’ahu:

$$
\text { SHDI }=-\sum_{i=1}^{n} p i \cdot \log p i,
$$

kde $p i$ je podiel rozlohy $i$-teho polygónu $\mathrm{k}$ celkovej rozlohe analyzovanej priestorovej jednotky reprezentovanej $n$ polygónmi. Jeho hodnota kolíše od 0 (žiadna diverzita) až po nekonečno. Hodnota SHDI sa zvyšuje s nárastom počtu plôšok a vyrovnanost'ou ich vel'kosti. Bližšie o problematike využitia krajinných metrík a použití SHDI píšu napr. Hanušin a Štefunková (2015).

Získané hodnoty SHDI sme vyjadrili vo výsledných mapách v piatich intervaloch tak, že sme súbory hodnôt pre jednotlivé obdobia zlúčili a z variačného rozpätia zlúčeného súboru sme získali pät' rovnakých intervalov spoločných pre všetky obdobia, čo umožnilo porovnávanie hodnôt KD medzi jednotlivými obdobiami. 
Intenzitu zmeny v období rokov 2010 až 1950 sme vyhodnotili ako rozdiel príslušných hodnôt SHDI.

Krajinnú diverzitu sme na všetkých úrovniach hodnotili v obidvoch sledovaných rokoch. Lokálna cestná siet' predstavuje dôležitú súčast' lazníckej krajiny, ktorá zabezpečuje spojenie lazov s obcou. Preto sme venovali pozornost' analýzam vlastností prírodnej krajiny, ktoré majú na smerovanie ciest zásadný význam. Mapovanie cestnej siete sme robili prostredníctvom kartografických podkladov a verejne prístupnej ortofotomapy Eurosense (Mapa.cz 2012) verifikovanej podrobným terénnym výskumom, ktorým sme doplnili údaje o technickom stave jednotlivých úsekov lokálnej cestnej siete. V zmysle metodiky pre vel'komierkový výskum, prezentovanej Urbánkom (1981) a modifikovanej Lacikom (2001), sme vyhodnotili mieru bariérovosti a spojitosti reliéfu vo vzt’ahu k cestnej sieti, akceptujúc topické hl'adisko (hl'adisko prvku a úseku), ako aj chorické hl'adisko (hl'adisko celku) tohto vzt’ahu. Jednotlivé segmenty vytvárajúce daný typ krajiny sú pre lokálnu cestnú siet' bariérou alebo spojkou. Za bariéru označujeme formy reliéfu vnímané ako prírodné prekážky st’ažujúce prepojenie bodov pospájaných cestnou siet’ou, spojky sú formami ul'ahčujúcimi budovanie a využívanie dopravných komunikácií. Vyčlenili sme areály s piatimi stupňami miery bariérovosti. Hlavným determinantom určovania miery bariérovosti boli topické a chorické vlastnosti prírodnej krajiny, dominantne jej geomorfologické parametre. Dostupnost' lazov od obce sme vyjadrili pomocou koeficientu predíženia, ktorý je daný pomerom reálnej vzdialenosti lazu po lokálnych cestách a vzdušnej vzdialenosti lazu od stredu dediny. Ďalšie parametre, ktoré podmieňujú dostupnost' lazov sú výškový profil prístupovej cesty a jej kvalita.

\section{CHARAKTERISTIKA ÚZEMIA A STRUČNÝ HISTORICKÝ VÝVOJ KULTÚRNEJ KRAJINY}

Väčšina katastrálneho územia Hrušova (rozloha 2331 ha) leží v západnej časti okresu Vel'ký Krtíš na rozhraní Ipel'skej kotliny a Krupinskej planiny. Podl'a geomorfologického členenia SR (Mazúr a Lukniš 1978) je severná čast' katastrálneho územia súčast'ou prírodnej krajiny členitej nekrasovej Dačolomskej planiny, južná čast' patrí do Modrokamenských úbočí s podstatne odlišnou morfometriou a morfodynamikou. Táto geomorfologická dualita územia sa prenáša aj do priestorovej diferenciácie ostatných zložiek prírodnej krajiny.

Pamät' súčasnej prírodnej krajiny Krupinskej planiny siaha do obdobia spodného badenu, najstaršie jednotky jej geologického podložia majú vyše 17 miliónov rokov (Vass et al. 1983). Sú tvorené komplexom vulkanicko-sedimentárnych hornín pochádzajúcich z vulkanických centier v okolí. V komplexe hornín prevažujú pyroklastiká, najmä tufitické piesky a brekcie. Od sarmatu prebiehal terestrický vývoj bez vulkanizmu formujúci základné geomorfologické črty dnešnej Krupinskej planiny bližšie charakterizovanej Lacikom (1997 a 2000). Nadmorské výšky kolíšu v rozmedzí 200 - $521 \mathrm{~m}$ n. m., plošiny v severnej časti dosahujú v priemere $450-490 \mathrm{~m}$ n. m. Klimaticky patrí územie do teplej, suchej až mierne suchej oblasti s miernou zimou (Lapin et al. 2012). Priemerná ročná teplota je približne $8,8^{\circ}$ $\mathrm{C}, \mathrm{v}$ januári okolo $-3{ }^{\circ} \mathrm{C}$ a v júli okolo $19{ }^{\circ} \mathrm{C}$. Priemerný ročný úhrn zrážok je nižší ako $600 \mathrm{~mm}$. Katastrálne územie leží na rozvodnej polohe prítokov Ipla. Slabo priepustné vulkanické horniny, nedostatok zrážok a poloha na rozvodí podmieňujú nízke zásoby podzemných vôd. V pôdnom kryte dominujú kambizeme. Prirodzenú 
potenciálnu vegetáciu tvoria tri stupne. Cerovo - dubové lesy a vyššie položené dubovo-hrabové lesy pokrývajú prevažnú čast' územia, v najvyšších polohách nad 500 m sú ostrovy podhorských bukových lesov (Maglocký 2002).

Hoci prvá písomná zmienka o Hrušove pochádza z roku 1272, predpokladá sa, že dnešná obec existovala už skôr. Približne v tomto období tu vznikala kultúrna krajina - sídlo Hrušov a obrábaná (pol’nohospodárska) krajina v jeho zázemí, ktorá sa postupne rozširovala najmä na sever, kde boli relatívne najpriaznivejšie podmienky pre pol'nohospodárstvo. Od stredoveku až do polovice 19. storočia sa uplatňovalo trojpol'né pol'nohospodárstvo. Zavíšsením procesu zmien vlastníkov po zrušení poddanstva bola komasácia - scel'ovanie pôdy, ktorá podmienila výrazné zmeny v charaktere krajinnej pokrývky. Vel'kostatkári väčšinou neboli z rôznych dôvodov schopní obrábat' svoje pozemky, ktoré sa po častiach postupne cez priekupníkov dostávali do rúk drobným miestnym rol'níkom. Tento proces prebiehal koncom 19. a začiatkom 20. storočia a sprevádzalo ho dočasné i trvalé spustnutie značnej časti vel'kostatkárskej pôdy. Posledný vel'kostatok sa rozpredal v roku 1930 (Brada et al. 2014).

Svojráznym krajinnotvorným prvkom Hrušova sú lazy, pomerne rovnomerne rozptýlené po celej ploche chotára. Presné obdobie ich vzniku nie je známe, predpokladá sa, že objekty na lazoch existovali už v stredoveku. Boli osídl'ované autochtónnym obyvatel'stvom (obyvatel'mi Hrušova) na rozdiel od väčšiny hontianskych obcí, v ktorých zakladali lazy prišelci zo severnejších regiónov, prezývaní horniaci (Švecová 1984). Postupne sa obydlia na lazoch transformovali zo sezónneho bývania na celoročné. Väčšina Hrušovčanov takto mala postupne dve bývania - jedno v obci, druhé na lazoch. Toto tzv. dvojité (dvojrezidenčné) bývanie sa naplno rozvinulo počas 1 . svetovej vojny, ked' boli muži na fronte a starost' o gazdovanie pripadla na ženy a starších l'udí (Brada et al. 2014). Bolo špecifické pre Hrušov, v okolitých obciach tento fenomén v takom rozsahu neexistoval. Ešte v roku 1991 bola z celkového počtu 437 domov v chotári Hrušova temer polovica postavená na lazoch (Škrdlová 2015). Dvojrezidenčnost' pretrvala prakticky celé minulé storočie a bezpochyby ovplyvnila aj charakter obhospodarovania pol'nohospodárskej krajiny. V období nástupu socializmu po roku 1950 v chotári Hrušova, na rozdiel od väčšiny územia Slovenska, nedošlo k typickej kolektivizácii pol'nohospodárstva do jednotných rol’níckych družstiev (JRD) a k prejavom v spôsobe využívania krajiny $\mathrm{s}$ ňou spojeným. Istou, pre miestnych rol'níkov prijatel'nejšou, náhradou JRD bol Zväz jednotlivo hospodáriacich rol'níkov (JHR) ktorý v Hrušove fungoval v rokoch 1968 - 1979 (Brada et al. 2014). Pričlenenie miestnych JHR ku JRD vo Vinici v roku 1979 ukončilo etapu prakticky úplnej dominancie malých rol'níkov v Hrušove. Lazy ako vysunuté jadrá obhospodarovania krajiny prakticky stratili svoj význam, mnohé z nich postupne zanikli, čo sa časom prejavilo aj na štruktúre pol'nohospodárskej krajiny.

Názov i hruška v znaku obce dokladujú, že pýchou Hrušova bolo ovocinárstvo, ktoré tu má stáročnú tradíciu. Ovocné sady síce nepredstavovali rozlohou vel'kú, ale svojím hospodárskym významom i percepčnou kvalitou neprehliadnutel'nú súčast' krajinnej pokrývky. Sadili sa v radoch na medziach, popri cestách, divo rastúce jedince rástli náhodne roztrúsené po celej obrábanej krajine. Napriek tomu, že sa vinič v obci pestoval už od 16. - 17. storočia, Hrušov nikdy nemal charakter typickej vinohradníckej obce. Prakticky všetka plocha kolíkových vinohradov bola v najjužnejšej časti chotára. 


\section{VÝSLEDKY}

Rámcové podmienky určujúce charakter krajinnej pokrývky a jej zmeny

Charakter krajinnej pokrývky a jej zmien (a následne aj charakter a zmeny KD v našom zmysle) sú výslednicou vzájomného pôsobenia politických, sociálnoekonomických podmienok, resp. zmien a relatívne stabilných vlastností prírodnej krajiny a polohy konkrétneho územia. V prípade Hrušova rámcujú charakter a zmeny LC nasledovné politické a sociálno-ekonomické podmienky:

- výrazne marginálna poloha Hrušova a okolitých obcí v rámci Slovenska, niekedy označovaná ako kumulovaná periférnost' (Halás 2008);

- zlá dopravná dostupnost', najbližšia železnica je vzdialená až 25 km (Šahy), cestné spojenie prechádzajúce chotárom $\mathrm{v}$ smere sever - juh bolo vybudované až v roku 1942;

- zmeny vlastníctva pôdy v období kolektivizácie. Aj ked' v tomto smere bola situácia v Hrušove menej dramatická ako vo väčšine iných obcí na Slovensku, aj tu sa pod zmeny LC podpísali viacnásobné zmeny vlastníckych pomerov prevažnej časti pol'nohospodárskej pôdy;

- demografické zmeny - po rastovej fáze vrcholiacej začiatkom 70. rokov minulého storočia nastal permanentný pokles počtu obyvatel'ov, starnutie populácie a najmä po roku 1990 trvalá, resp. sezónna emigrácia časti mladých a vzdelaných ludí za prácou mimo obec, aj ked' v posledných rokoch zaznamenávame náznaky určitej demografickej obnovy lazov;

- istá etnická a náboženská výlučnost' voči okoliu. Okolité obce smerom na juh sú prevažne mad’arské a katolícke, susedné obce v Krupinskej planine sú prevažne slovenské a evanjelické. Tieto danosti spolu so slabou prirodzenou dostupnost'ou do okolitých obcí (s výnimkou Vinice) dotvárali v minulosti v dominantne slovensko-katolíckom Hrušove stav istej izolovanosti, z ktorej vyplýval tlak na sebestačnost', samozásobitel'stvo a spoliehanie sa na vlastné sily.

Z hladiska prírodného sú rozhodujúce:

- makropoloha chotára na rozhraní Slovenského stredohoria a Lučensko-košickej zníženiny v klimatickom dosahu Podunajskej nížiny (resp. Malej dunajskej kotliny);

- malé zdroje a zásoby povrchových a podzemných vôd. Hydrogeologické vlastnosti sopečných hornín sú nevhodné na akumuláciu väčších zásob podzemnej vody, k čomu sa pridružuje absencia významnejších povrchových tokov podmienená polohou chotára na rozvodí;

- klimatická zmena - za 60-ročné obdobie došlo v dôsledku zmien klímy (ktorých prejavy sú extrémnejšie na južnom Slovensku) na stanici Hurbanovo k poklesu priemerných zrážkových úhrnov v teplom polroku (apríl - september) asi o $10 \%$ a $\mathrm{k}$ nárastu priemerných teplôt vzduchu v tom istom období o približne $0,6^{\circ} \mathrm{C}($ Lapin 2012). Tento trend môžeme s malou odchýlkou aplikovat' aj na chotár Hrušova. 


\section{Analýza zmien krajinnej pokrývky a krajinnej diverzity na celom území a v prírodných krajinných jednotkách}

Skúmané roky (1950 a 2010) neumožňujú zachytit' dynamiku zmien LC v medziobdobí, ktoré patrí z hl'adiska vlastníckych zmien $\mathrm{k}$ pôde $\mathrm{k}$ najdynamickejším $\mathrm{v}$ histórii obce. Najvýznamnejšie zmeny v charaktere LC v rámci sledovaného obdobia nastali po založení JRD v roku 1979, ktoré obrábalo pôdu socialistickým vel'kovýrobným spôsobom len asi do roku 1990. Na základe analýzy vzorcov (patternov) LC sa dá predpokladat', že ani po tomto období nedošlo k výraznému zvratu a návratu $\mathrm{k}$ spôsobu využívania krajiny spred roku 1979. Zmeny jednotlivých kategóríi LC sú zrejmé z tab. 2. Zásadnou zmenou medzi rokmi 1950 a 2010 bol výrazný nárast lesov (o 19 \%, najmä v PKT vo východnej a južnej časti územia). Najvýraznejší pokles zaznamenala orná pôda (ORP) o $13 \%$, a to najmä v PKT v strednej a južnej časti územia. Rozloha zastavanej plochy intravilánu obce vzrástla temer dvojnásobne, naproti tomu zástavba na lazoch (kde sú započítané aj pridomové záhrady) vzrástla asi o $24 \%$. Celková rozloha rozptýlenej zástavby na lazoch zostala však stále väčšia ako kompaktná zástavba intravilánu obce. Napriek tomu, že v sledovanom období zaznamenala rozloha ORP najväčší úbytok, reálne straty zornených plôch nie sú také dramatické, pretože čast' ORP sa transformovala na kategóriu pol'nohospodárskych mozaík s NDV do $20 \%$, ktoré zostali čiastočne zornené, a ktorá zaznamenala po lesoch najväčší, temer 90 -percentný plošný nárast, prevažne na menej členitých formách reliéfu (planiny v severnej časti chotára a mierne členené zníženiny v juhovýchodnej časti). Najväčší pokles lúk a pasienkov sme zaregistrovali v severnej planinovej časti, čo spolu s poklesom kategórie lúky so sukcesiou NDV poukazuje na výrazný pokles pasenia v chotári. S výnimkou severnej časti zaberali lesy v roku 1950 marginálne polohy najmä na hranici chotára, popritom sa výrazne koncentrovali v južnej časti územia. Najväčší nárast lesov a NDV k roku 2010 sa sústredil východne od severojužnej osi chotára (tvorí ju približne štátna cesta Vinica - Hrušov - križovatka s cestou I/75), kde novovzniknuté lesy nadväzujú na existujúce lesy na východnej hranici chotára. Na opačnej strane, t. j. západne od spomínanej osi, dominujú územia bez zmeny, táto čast' chotára je z hl'adiska zmien LC menej dynamická.

$\mathrm{V}$ charaktere zmien LC dominujú územia bez zmeny, zaberajúce viac ako polovicu rozlohy. Kategória „ostatné zmeny“ predstavuje temer pätinu zmien LC. Dalšiu čast' zmien môžeme charakterizovat' ako zmeny smerujúce k sprírodneniu krajiny (extenzifikácia pol’nohospodárstva a zalesnenie), ktoré nastali približne na $35 \%$ rozlohy chotára. Najmenší podiel mali zmeny smerujúce k odprírodneniu chotára (intenzifikácia pol'nohospodárstva, odlesnenie a urbanizácia), ktoré nastali približne na $11 \%$ rozlohy chotára.

Základným prejavom zmien KD v sledovaných obdobiach je pokles KD v roku 2010 v porovnaní s rokom 1950 v prevažnej časti chotára (SHDI v celom študovanom území bol v roku 1950 - -2,367, v roku $2010--2,041)$. Vyššiu KD v roku 2010 sme identifikovali asi na 12 \% rozlohy, menovite v 5 z 21 čiastkových PKJ. Kolektivizácia, centralizácia a mechanizácia pol’nohospodárskej výroby spojená s úbytkom l'udí na lazoch podmienili zmeny, ktoré sa prejavili v znížených hodnotách KD v roku 2010. Prejavom týchto zmien bolo o. i. spájanie pôvodne rozdrobených menších enkláv lesov roztrúsených po prevažne pol'nohospodárskej krajine sukcesiou. 
Tab. 2. Rozlohy a podiel kategórií krajinnej pokrývky

\begin{tabular}{|c|c|c|c|c|c|c|}
\hline Kategória LC & $\begin{array}{l}1950 \\
\text { (ha) }\end{array}$ & $\begin{array}{l}1950 \\
(\%)\end{array}$ & $\begin{array}{c}2010 \\
\text { (ha) }\end{array}$ & $\begin{array}{c}2010 \\
(\%)\end{array}$ & $\begin{array}{c}\text { Zmena } \\
\text { 2010-1950 } \\
\text { (ha) }\end{array}$ & $\begin{array}{c}\text { Zmena } \\
\text { 2010-1950 } \\
(\%)\end{array}$ \\
\hline kompaktná obytná zástavba & 15,91 & 0,68 & 29,28 & 1,26 & 13,37 & 0,57 \\
\hline $\begin{array}{l}\text { zástavba na lazoch vrátane } \\
\text { pridomových záhrad }\end{array}$ & 30,40 & 1,30 & 37,70 & 1,62 & 7,3 & 0,31 \\
\hline cesty (vybraná siet') & 12,79 & 0,55 & 11,72 & 0,50 & $-1,07$ & $-0,05$ \\
\hline $\begin{array}{l}\text { pol'nohospodárske výrobné } \\
\text { areály }\end{array}$ & 0,00 & 0,00 & 5,65 & 0,24 & 5,65 & 0,24 \\
\hline degradované plochy & 3,09 & 0,13 & 2,14 & 0,09 & $-0,95$ & $-0,04$ \\
\hline orná pôda & 704,68 & 30,23 & 398,00 & 17,07 & $-306,68$ & $-13,16$ \\
\hline vinice & 12,72 & 0,55 & 13,78 & 0,59 & 1,06 & 0,05 \\
\hline ovocné sady (extenzívne) & 25,47 & 1,09 & 6,70 & 0,29 & $-18,77$ & $-0,81$ \\
\hline lúky a pasienky & 535,58 & 22,98 & 317,04 & 13,60 & $-218,54$ & $-9,38$ \\
\hline $\begin{array}{l}\text { pol'nohospodárske mozaiky } \\
\text { s NDV do } 20 \%\end{array}$ & 34,26 & 1,47 & 274,17 & 11,76 & 239,91 & 10,29 \\
\hline $\begin{array}{l}\text { pol'nohospodárske mozaiky } \\
\text { s NDV nad } 20 \%\end{array}$ & 1,13 & 0,05 & 46,31 & 1,99 & 45,18 & 1,94 \\
\hline $\begin{array}{l}\text { lúky so sukcesiou NDV } \\
\text { do } 20 \%\end{array}$ & 199,43 & 8,56 & 43,32 & 1,86 & $-156,11$ & $-6,70$ \\
\hline $\begin{array}{l}\text { lúky so sukcesiou NDV } \\
\text { nad } 20 \%\end{array}$ & 78,12 & 3,35 & 18,62 & 0,80 & $-59,50$ & $-2,55$ \\
\hline lesy a NDV & 677,17 & 29,05 & 1126,24 & 48,32 & 449,07 & 19,27 \\
\hline $\begin{array}{l}\text { vodná plocha (2010), mokrad' } \\
(1950)\end{array}$ & 1,18 & 0,05 & 0,67 & 0,03 & $-0,51$ & $-0,02$ \\
\hline
\end{tabular}

Zmeny KD v jednotlivých PKT mali odlišný charakter (obr. 4). Plošiny (PKT A1) si udržali v obidvoch obdobiach najvyššiu, resp. druhú najvyššiu (v roku 2010) hodnotu KD, čo je dôsledkom ich kontinuálneho intenzívneho obrábania a relatívne nízkej dynamiky zalesňovania. Plytká dolina na planine (PKT A2) patrí medzi štyri PKJ, v ktorých sa k roku 2010 hodnota KD zvýšila, v prípade daného PKT najvýraznejšie. Nárast KD podmienilo najmä zalesňovanie, ktoré tu bolo relatívne najvýraznejšie spomedzi všetkých PKT. Nemalo však masívny plošný charakter, ani pri ňom nedochádzalo k spájaniu malých enkláv lesov do väčších blokov, ale udialo sa väčšinou formou vzniku menších izolovaných plôšok, čo ovplyvnilo nárast KD. Najvyššia KD v PKT mierne členené zníženiny (PKT B1) v obidvoch rokoch je do vel'kej miery podmienená vel'kým počtom sídiel, vrátane intravilánu Hrušova. V jeho zázemí je vysoký podiel mozaík diverzifikovaných malých plôch s pol'nohospodárskym využívaním, zvyšujúcich hodnoty KD. Strmé dolinové svahy (PKT B2) zaznamenali najvyšší pokles KD v sledovanom období. Hlavnou príčinou je homogenizácia LC intenzívnym zalesňovaním. V obidvoch obdobiach to bol PKT s najvyšším podielom lesa. Pät' PKJ v rámci PKT izolované elevácie (PKT B3) vykazuje značné rozdiely v hodnotách KD. Zmeny KD v tomto PKT ako celku boli jedny z najmenších. Ploché rázsochy (PKT B4), podobne ako predo- 
šlý PKT, sa vyznačujú heterogenitou KD medzi jednotlivými PKJ. Dolinové dno (PKT 5) má ako celok nízke hodnoty KD. Aj vel'kost' zmien KD je tu najnižšia spomedzi všetkých PKT. Plytká dolina na úboči (B6) bola v roku 1950 homogénnym PKT s nízkou KD podmienenou prevládajúcimi lúkami a pasienkami. Druhý najvyšší nárast KD spomedzi $21 \mathrm{PKJ}$ tu zapríčinila výstavba pol'nohospodárskeho areálu a intenzifikácia časti lúk a pasienkov. Členená dolina (B7), najmenší PKT a zároveň aj PKJ má najvyšší stupeň sprírodnenia spomedzi všetkých PKJ. Podiel ORP tu poklesol z temer $50 \%$ v roku 1950 na nulu v roku 2010, prevažnú čast' ORP nahradili lesy a NDV.

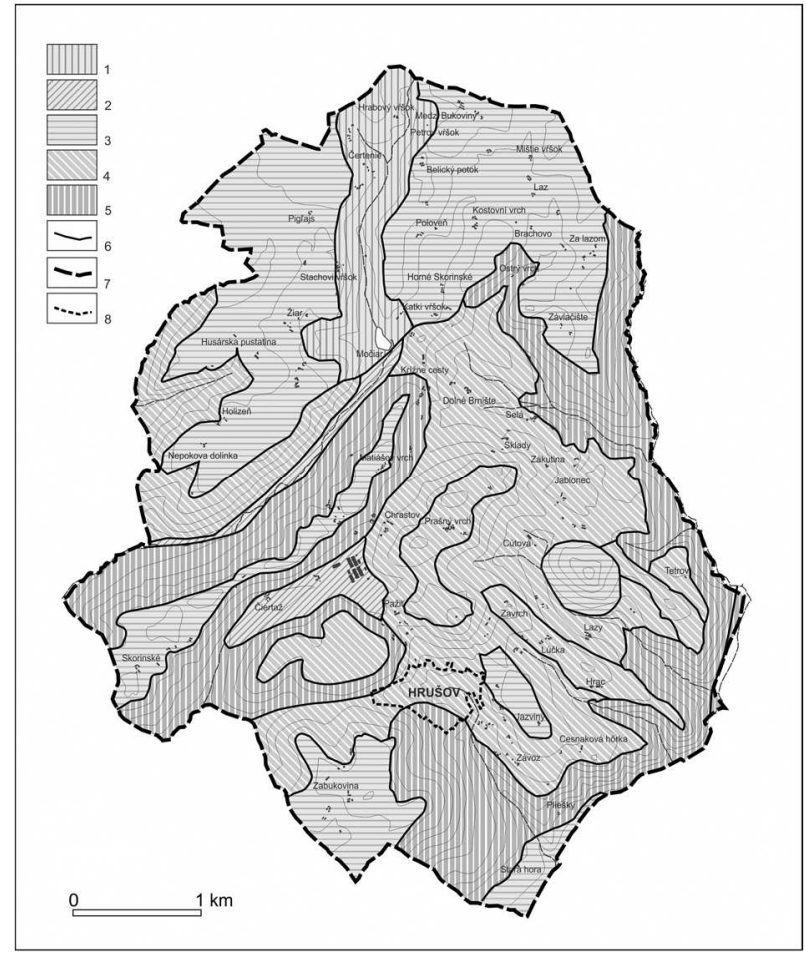

Obr. 4. Zmeny SHDI v prírodných krajinných jednotkách

Legenda: Zmena hodnoty SHDI: $1--0,660--0,360$ (SHDI vyšší v roku 2010), $2--0,359--0,050$, $3-0,049-0,260,4-0,261-0,570,5-0,571-0,867$ (SHDI vyšší v roku 1950), 6 - hranice PKJ, 7 - hranica katastrálneho územia, 8 - hranica intravilánu Hrušov.

Analyzovali sme prípadnú súvislost' medzi charakterom dominantných zmien LC v PKT a priemernou zmenou KD v PKT, ktorú sme určili ako vážený priemer zmien KD v príslušných PKJ. Dominantná zmena LC je typ zmeny LC s najvyšším podielom na rozlohe $\mathrm{v}$ danom PKT. Vzhl'adom na vel'kost' rozptylu hodnôt zmien KD v jednotlivých typoch zmien LC, v študovanom území nepredpokladáme žiadnu súvislost' medzi týmito procesmi (tab. 3). 
Tab. 3. Dominantná zmena LC a priemerná zmena KD v PKT

\begin{tabular}{cccccc}
\hline KT & $\begin{array}{c}\text { Dominantná } \\
\text { zmena LC }\end{array}$ & $\begin{array}{c}\text { Priemerná } \\
\text { zmena KD }\end{array}$ & KT & $\begin{array}{c}\text { Dominantná } \\
\text { zmena LC }\end{array}$ & $\begin{array}{c}\text { Priemerná } \\
\text { zmena KD }\end{array}$ \\
\hline A1 & E & 0,035 & B4 & Z & 0,218 \\
A2 & Z,E,I & $-0,660$ & B5 & Z & $-0,181$ \\
B1 & Z,I & 0,388 & B6 & I & $-0,253$ \\
B2 & Z & 0,788 & B7 & E & $-0,001$ \\
B3 & E & 0,183 & & & \\
\hline
\end{tabular}

Dominantná zmena LC: E - extenzifikácia pol'nohospodárstva, I - intenzifikácia pol’nohospodárstva, $\mathrm{Z}$-zalesnenie.

Analýza zmien krajinnej pokrývky a krajinnej diverzity v zázemí lazov

Analýza údajov LC (tab. 4) ukazuje, že v zázemí sídiel (kruhové areály so sídlom) došlo $\mathrm{k}$ zalesneniu $\mathrm{v}$ menšej miere ako je priemer celého územia a súčasne tu nastal výrazný úbytok ornej pôdy, výrazne vyšší ako priemer za celé územie. Intenzívny proces opúšt'ania pol'nohospodárskej pôdy naznačuje temer sedemnásobný nárast podielu sumy plôch so sukcesiou. Vyhodnotenie týchto procesov vedie k záveru, že prinajmenšom $\mathrm{v}$ sledovaných areáloch zázemia lazov nastala značná extenzifikácia pol'nohospodárskej výroby dokumentovaná poklesom rozlohy ornej pôdy a nárastom sukcesných plôch a že tieto procesy tu boli intenzívnejšie ako na ostatnom území.

Tab. 4. Zmeny vybraných kategórií LC a KD v kruhových areáloch

\begin{tabular}{|c|c|c|c|c|c|}
\hline Typy kruhových areálov & $\begin{array}{l}\text { Lesy a NDV } \\
(\% \text { rozlohy })\end{array}$ & $\begin{array}{l}\text { Orná pôda } \\
(\% \text { rozlohy })\end{array}$ & $\begin{array}{c}\text { Lúky a } \\
\text { pasienky } \\
(\% \text { rozlohy })\end{array}$ & $\begin{array}{l}\text { Suma plôch } \\
\text { areálov } \\
\text { so sukcesiou } \\
\text { (\% rozlohy) }\end{array}$ & $\begin{array}{l}\text { Krajinná diverzi- } \\
\text { ta (priemerné } \\
\text { hodnoty SHDI } \\
\text { v kruh. areáloch) }\end{array}$ \\
\hline $\begin{array}{l}\text { Kruhové areály so sídlom } \\
1950\end{array}$ & 6,6 & 47,3 & 16,9 & 7,9 & $-0,656$ \\
\hline $\begin{array}{l}\text { Kruhové areály so sídlom } \\
2010\end{array}$ & 13,2 & 24,4 & 15,5 & 28,2 & $-0,685$ \\
\hline Rozdiel (2010 - 1950) & 6,6 & $-22,9$ & $-1,5$ & 20,3 & $-0,029$ \\
\hline $\begin{array}{l}\text { Kruhové areály bez sídla } \\
1950\end{array}$ & 45,9 & 21,7 & 19,1 & 27,6 & $-0,451$ \\
\hline $\begin{array}{l}\text { Kruhové areály bez sídla } \\
2010\end{array}$ & 82,1 & 16,4 & 5,9 & 9,7 & $-0,221$ \\
\hline Rozdiel (2010 - 1950) & 36,2 & $-5,3$ & $-13,2$ & $-17,9$ & 0,230 \\
\hline $\begin{array}{l}\text { Celé katastrálne územie } \\
\text { Hrušov } 1950\end{array}$ & 24,0 & 30,0 & 23,0 & 13,5 & $-2,367$ \\
\hline $\begin{array}{l}\text { Celé katastrálne územie } \\
\text { Hrušov } 2010\end{array}$ & 48,0 & 17,0 & 13,0 & 16,5 & $-2,041$ \\
\hline Rozdiel $(2010-1950)$ & 24,0 & $-13,0$ & $-10,0$ & 3,0 & $-0,326$ \\
\hline
\end{tabular}

Zdroj: vlastný výpočet. 
Priemerná hodnota KD v areáloch so sídlom sa v sledovaných rokoch mierne zvýšila, zatial' čo v areáloch bez sídla poklesla približne na polovicu. Znamená to, že KD meraná indexom SHDI v okolí lazov mierne rástla, v areáloch mimo lazov sledovala celoplošný trend poklesu SHDI v roku 2010 v porovnaní s rokom 1950. Táto zmena nastala aj napriek tomu, že počet plôšok (patches) sa v kruhových areáloch so sídlami k roku 2010 mierne znížil, čo by naznačovalo zníženie KD.

\section{Vývoj a charakteristika lokálnej cestnej siete}

Krupinská planina, ktorej súčast'ou je kataster obec Hrušov, je špecifickým prírodným prostredím významným spôsobom ovplyvňujúcim charakter a rozloženie komunikačnej siete a už v minulosti predstavovala výraznú prírodnú prekážku st'ažujúcu komunikačné spojenie medzi južnejšie ležiacimi stolicami niekdajšieho Uhorska a bohatým stredoslovenským banským regiónom. Podla Bradu a Brloša (2013) túto bariéru prekonávala jediná cesta vyššieho ako lokálneho významu. Dolinou Vel'kého potoka na východnom okraji hrušovského chotára viedla jedna z vedl'ajších obchodných ciest smerujúcich z južných oblastí Hontu cez Čelovce $\mathrm{k}$ banským mestám na strednom Pohroní. Hrušov bol koncovou dedinou spojenou tzv. vicinálnou cestou s ned'alekou obcou Nekyje (dnes Vinica). V rokoch 1942 až 1968 sa táto cesta predížila napojením na dnešnú cestu 1. triedy č. 75 trasovanú medzi Pláštovcami a Čebovcami po plošinách Krupinskej planiny.

Pre laznícke obce na Slovensku je charakteristická väčšia dížka a hustota siete lokálnych ciest, ktoré zabezpečujú spojenie roztratených sídiel so strediskovou obcou (ústredím). Platí to aj o katastri Hrušova, na území ktorého sa nachádza temer $53 \mathrm{~km}$ lokálnych ciest (hustota $2,3 \mathrm{~km}$ na $1 \mathrm{~km}^{2}$ ). Mapa lokálnej cestnej siete nám poskytuje informácie o vzdialenosti jednotlivých lazníckych usadlostí od dediny (merané od stredu historickej časti obce) a po zohl'adnení stavu cesty a jej výškového profilu aj o ich odl'ahlosti. Podl'a výsledkov výskumu dostupných historických kartografických podkladov je zrejmé, že súčasná siet' lokálnych ciest v katastri Hrušova sa v podstate nelíši od siete ciest vytvorenej v dávnejšej minulosti. Stavitelia prvotných lokálnych ciest medzi dedinou a lazníckymi usadlost’ami do značnej miery rešpektovali prírodné danosti determinované predovšetkým geomorfologickými vlastnost’ami prírodnej krajiny. Trasovanie historických aj súčasných ciest rešpektuje mieru bariérovosti jednotlivých segmentov prírodných krajinných typov vyskytujúcich sa v hrušovskom katastri. Hodnota koeficientu predíženia sa pohybuje v rozpätí od 2,21 po 1,14. Nízke hodnoty dosahujú lazy ležiace blízko hlavnej komunikácie, ktorá prechádza pomerne priamočiaro stredom katastra od severu na juh. Vysoké hodnoty sme zistili pri lazoch na okrajoch katastra dostupné po cestách vedúcich po plošinách a plošinových chrbtoch obchádzajúcich doliny. Výškové profily ciest z lazov do dediny identifikujú početnost' lokálnych bariér na trase. Dostupnost' lazov je značne ovplyvnená kvalitou ciest, ktorá je na obr. 5 vyjadrená 4-stupňovou škálou od asfaltových ciest po zarastajúce cesty a chodníky. V mape je znázornená aj miera bariérovosti prírodnej krajiny.

V podmienkach Slovenska, kde sa sídelno-komunikačná siet' sústred'uje prevažne do depresných častí, sú bariérami horské chrbty a hrebene, spojkami sú kotliny, doliny a sedlá v horských hrebeňoch. V katastrálnom území Hrušova sa však vyvinul inverzný typ využívania krajiny. Laznícke usadlosti spolu so siet’ou lokálnych ciest nachádzame prevažne vo výšinnej polohe. Vel'mi nízku mieru bariérovosti vykazujú náhorné plošiny planiny, ktoré umožňujú komunikačné prepojenie medzi 
lazmi takmer všetkými smermi. Plytká dolina planiny, ako aj ploché dná väčších dolín majú nízku mieru bariérovosti umožňujúcu l'ahké komunikačnej prepojenie v smere osi danej doliny. Strednú mieru bariérovosti sme priradili areálom lokálnych náhorných plošín, ktoré sú obklopené areálmi s vyššou mierou bariérovosti. Vysokú a vel'mi vysokú mieru bariérovosti nachádzame na členitejších dolinových svahoch úbočí Krupinskej planiny, ktoré svojimi geomorfologickými parametrami výraznejšie st’ažujú komunikačné prepojenie medzi lazmi.

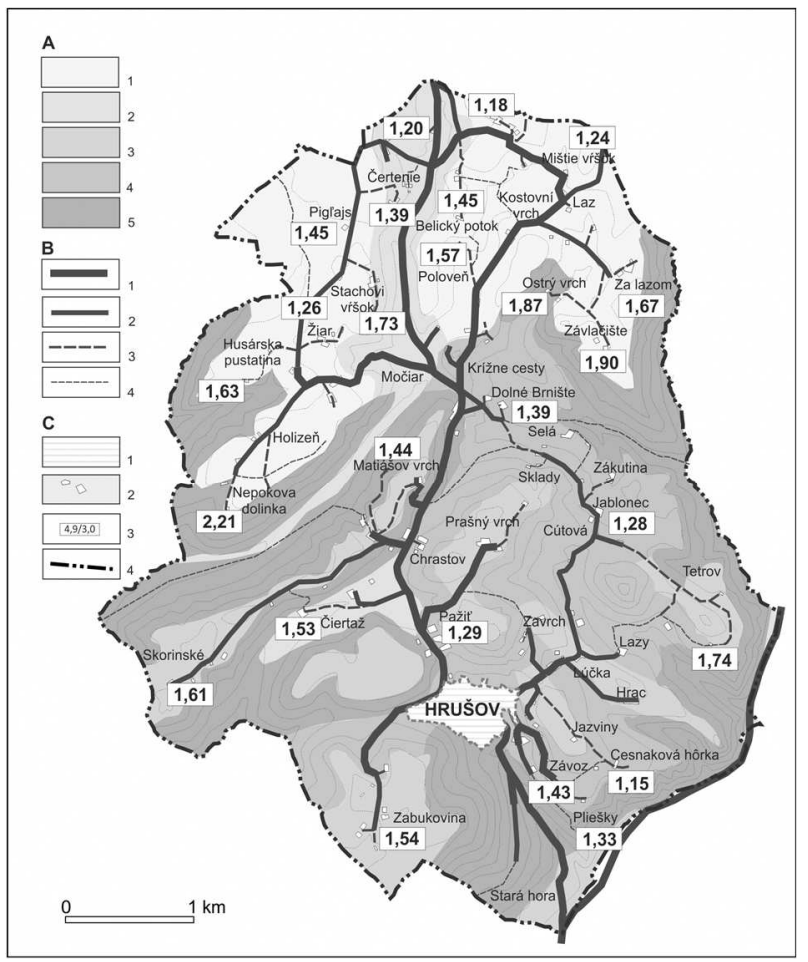

Obr. 5. Bariérovost' prírodnej krajiny a kvalita ciest

Legenda: A Miera bariérovosti prírodnej krajiny: 1 - vel'mi nízka, 2 - nízka, 3 - stredne vysoká, 4 vysoká, 5 - vel'mi vysoká.

B Kvalita ciest: 1 - asfaltová cesta, 2 - spevnená cesta bez asfaltového povrchu, 3 - málo spevnená cesta, 4 - zarastená cesta alebo chodník.

C Ostatné značky: 1 - intravilán obce, 2 - laznícke sídla, 3 - koefícient predíženia, 4 - hranica katastrálneho územia.

Planinové plošiny a plošinové chrbty Dačolomskej planiny sú spojkami a nižšie ležiaca dolinová siet' Modrokamenských úbočí je bariérou. Výnimkou je hlavná cestá komunikácia umožňujúca spojenie Hrušova s okolím, je trasovaná do dolín. Cesta z Hrušova do Vinice vedie pomerne úzkou a strmou dolinou, ktorá v minulosti zabezpečovala prirodzenú ochranu dediny. Cesta z Hrušova na sever stúpa do výrazného sedla a planinovú krajinu pretína po dne plytkej doliny mierne zahíbenej do planinových plošín. Systém chrbtov a dolín v severnej časti katastrálneho územia Hrušova inklinuje smerom na juhozápad. Z hladiska polohy dediny je však 
tento smer pre lokálnu cestnú siet' nevyužitý. Rozhranie medzi vnútornými plošinami a svahmi úbočí Krupinskej planiny nie je v tomto úseku príliš silnou bariérou.

\section{DISKUSIA}

Študované územie predstavuje svojrázny, v minulosti relatívne izolovaný, sociálne a hospodársky autonómny mikroregión s vyvinutým systémom rozptýleného osídlenia, v ktorom sa vytvárali špecifické vzt’ahy medzi hlavným sídlom (Hrušov) a lazmi, ako aj vzt’ahy medzi lazmi navzájom. Aj v súčasnosti patrí Hrušov medzi obce v marginálnych regiónoch. Porovnanie zmien LC zo študovaného územia so zmenami v jeho širšom zázemí (územie okresov Levice a Zvolen v zmysle administratívneho členenia pred rokom 1968, údaje za rok 1950, resp. sumár za súčasné okresy Levice, Zvolen, Detva, Krupina a Vel'ký Krtíš, údaje za rok 2010), vykazuje v kategórii orná pôda opačné výsledky. Zatial' čo v roku 1950 bol v širšom zázemí podiel ornej pôdy 36,6 \% (Mazúr 1974), a v roku 2010 na rovnakom území bol jej podiel dokonca o jedno percento vyšší (37,6 \%); (ÚGKK SR 2011), v chotári Hrušova sme zaznamenali významný pokles podielu ornej pôdy o približne $13 \%$. V prípade lesov došlo v širšom zázemí Hrušova k nárastu ich podielu z 23 \% v roku 1950 na 31 \% v roku 2010, čo je zmena zhodná so študovaným územím, tu však bola intenzita zalesnenia výraznejšia (nárast podielu lesov o 19 \% v Hrušove v porovnaní s nárastom o $8 \% \mathrm{v}$ širšom zázemí). Z hl'adiska porovnania zmien LC sú chotáru Hrušova bližšie regióny s významným zastúpením rozptýleného osídlenia. Z výsledkov štúdie, ktorú v novobanskej štálovej oblasti na hornej Žitave spracoval Petrovič vyplýva, že v troch obciach tohto regiónu medzi rokmi 1956 a 2002 došlo $\mathrm{k}$ poklesu podielu obrábanej pôdy z 18 na $10 \%$ a súčasne k nárastu podielu lesa vrátane NDV zo 49 na 59 \% (Petrovič 2006), čo sú zmeny porovnatel’né so študovaným územím, avšak $\mathrm{s}$ menšou intenzitou, ktorá ale môže byt' podmienená aj kratším sledovaným obdobím. Tieto porovnania naznačujú mimoriadnu intenzitu základných zmien LC - opúšt’anie ornej pôdy (extenzifikácia pol'nohospodársta) a súčasne zalesňovanie v chotári Hrušova v porovnaní s inými príbuznými regiónmi. Porovnanie rozsahu ORP v roku 1950 v širšom kontexte zasa umožňujú zistenia Hromádku z údajov z roku 1929, ktoré vzhl’adom na malú dynamiku zmien LC v predkolektivizačnom období považujeme za porovnatel'né s údajmi z roku 1950. Približne 30-percentný podiel ORP v roku 1950 v Hrušove je zhruba rovnaký, aký udáva za rok 1929 pre kopaničiarske oblasti Javorníkov a Kysúc, je však o niečo nižší ako podiel ornej pôdy v celom okrese Krupina, kde v roku 1929 dosahoval 35 - 40 \% (Hromádka 1943).

Pri interpretácii niektorých kategórií LC najmä v roku 1950 sme boli limitovaní slabšou kvalitou snímok v porovnaní s rokom 2010 vyplývajúcou z dobových technických možností. Preto interpretácia prechodných kategórií LC, napr. lúky a pasienky, pol'nohospodárske mozaiky s NDV a lúky so sukcesiou NDV, nebola vždy jednoznačná. V sledovanom období vzrástla kategória LC zástavba na lazoch vrátane pridomových záhrad temer o štvrtinu. Štatistiky však naznačujú, že počet obyvatel'ov a obývaných domov na lazoch dosiahol svoj vrchol niekedy v období rokov 1965 - 1970. Najmä po pričlenení miestnych rol'níkov ku JRD vo Vinici v roku 1979 nastal odliv obyvatel'ov z lazov do ústredia. Podl'a databázy obecného úradu žilo ešte v roku 1990 na lazoch asi 415 obyvatel'ov, v roku 2016 len asi 230. Počet domov na lazoch sa však neznížil, väčšina domov stojí, aj ked' neobývaných, prípadne zmenených na rekreačné objekty. V roku 1991 bolo v Hrušove trvale obývaných 278 domov a neobývaných až 159 domov, teda $36 \%$ domového fondu 
(Škrdlová 2015). Z leteckých snímok nie je pochopitel'ne možné spol’ahlivo identifikovat' obývanost'/neobývanost' konkrétneho objektu, sídla, lazu. Preto nárast rozlohy kategórie LC zástavba na lazoch vrátane pridomových záhrad o štvrtinu k roku 2010 v žiadnom prípade nemožno interpretovat' ak rozvoj bývania na lazoch. Vel'kú čast' identifikovanej zástavby tu tvoria opustené, neobývané objekty. Z nášho pohl'adu bol prekvapivý, aj ked' len mierny nárast KD v kruhových areáloch so sídlami k roku 2010, čo je opačný trend v porovnaní so zmenami KD na strednej úrovni (PKT/PKJ). Porovnanie závislosti typu zmien LC a priemernej zmeny KD v PKT nepreukázalo žiadnu závislost' medzi týmito procesmi. Alternatívne vyhodnotenie väčšieho počtu kruhových areálov spolu s problematikou demografického vývoja a domového fondu na lazoch by mali byt' d'alšími výskumnými témami v tejto lokalite. Trasovanie ciest v území sa vel'mi nezmenilo. K stabilite smerovania ciest prispel pomerne členitý terén, ktorý len minimálne umožňuje alternatívne trasy, a spolu s ním aj relatívne krátkodobá a nie intenzívna kolektivizácia pol’nohospodárskej výroby v chotári, počas ktorej nedošlo k zásadným zmenám usporiadania LC.

\section{ZÁVER}

Analýza zmien LC a KD patrí k štandardným nástrojom hodnotenia krajinných zmien, umožňujúcim popri iných benefitoch identifikovat' zmeny v prírodnej krajine a v spoločnosti, vymedzit' ich intenzitu a rozsah a na základe získaných poznatkov navrhnút' odstránenie alebo minimalizáciu negatívnych javov a procesov, alebo naopak, posilnenie pozitívnych javov a procesov. Výsledkom štúdie je vyhodnotenie zmien LC a KD v troch priestorových úrovniach na príklade lazníckej obce so svojráznou krajinnou a najmä sídelnou štruktúrou. Systém lazov, svojím vznikom a fungovaním na Slovensku unikátny, podmienil niektoré anomálie vo vývoji LC typické pre marginálne regióny, resp. územia s rozptýleným osídlením - oneskorenú, neúplnú, prípadne žiadnu kolektivizáciu. Na druhej strane ústup a čiastočný zánik lazov vyvolal zmeny LC, ktorých intenzita presiahla priemerné hodnoty bežné v širšom regióne (najmä opúšt’anie ornej pôdy - extenzifikácia pol’nohospodárstva a zalesnenie). Uvedené zmeny podmienili aj pokles KD v roku 2010, a to najmä z dôvodu zániku roztrúsených enkláv lesa a NDV a ich scel'ovania do kompaktnejších celkov. Lokálna cestná siet' neprešla v ostatných desat'ročiach výraznejšou transformáciou, zachovala si približne rovnaký pôdorys, výrazne sa však zmenila kvalita ciest. Len v malej miere došlo k tomu, že takmer alebo úplne zaniklo niekol'ko krátkych úsekov vedúcich k okrajovým dlhodobejšie nevyužívaným usadlostiam. Ovel'a väčší rozsah má proces skvalitňovania technického stavu ciest. Lepšia dostupnost' lazníckych usadlostí je jedným z dôležitých stimulov revitalizácie autentickej lazníckej krajiny, ktorá sa oživuje zvýšeným záujmom tzv. novolazníkov usadit' sa v Hrušove.

Predložená štúdia sa primárne venovala problematike zmien LC, KD a ciest. Na získanie komplexného obrazu fungovania a vplyvu lazníckeho osídlenia na študované územie bude potrebné spracovat' d'alšie analýzy týkajúce sa najmä problematiky sídiel (lazov) a demografických charakteristík.

Príspevok bol spracovaný v rámci projektu VEGA č. 2/0023/15.

Niektoré časti príspevku boli použité v kapitole pod názvom: Transformácia historickej kultúrnej krajiny s rozptýleným osídlením (na príklade obce Hrušov, okres Vel'ký Krtíš), ktorá je súčast'ou Geographie Slovaca 3/2017. 


\section{LITERATÚRA}

BOLTIŽIAR, M. (2007). Hodnotenie vývoja heterogenity a vybraných charakteristík plôšok krajinnej štruktúry. Acta Environmentalica Universitatis Comenianae, 15, 68-79.

BOTÍK, J. (1980). Dvojrezidenčnost' ako dôsledok lazového osídlenia. Slovenský národopis, 28(1), 78-83.

BRADA, P., ZRNÍKOVÁ, K., BRLOŠ, J. (2014). Rolníctvo v Hrušove. Hrušov (Obec Hrušov).

BRADA P., BRLOŠ, J. (2013). Tradičné stavitel'stvo v Hrušove. Hrušov (Obec Hrušov).

FARINA, A. (2006). Principles and methods in landscape ecology. Towards a science of landscape. Landscape Series, Volume 3. Dordrecht (Springer).

FEKETE, Š. (1947). Typy vidieckeho osídlenia na Slovensku. Spisy Slovenskej zemepisnej spoločnosti, 1, 7-17.

FERANEC, J., OTTAHEL, J. (1999). Mapovanie krajinnej pokrývky metódou CORINE v mierke 1: 50 000: návrh legendy pre krajiny programu Phare. Geografický časopis, $51,19-44$.

FERANEC, J., OŤAHEL', J. (2009). Land cover/land use change research and mapping in Slovakia. Geographia Slovaca, 26, 169-190.

FERANEC, J., ŠURI, M., CEBECAUER, T. OŤAHEL, J. (2002). Methodological aspects of landscape changes detection and analysis in Slovakia applying the CORINE land cover databases. Geografický časopis, 54, 271-288.

GUSTAFSON, E. J. (1998). Quantifying landscape spatial pattern: What is the state of the art? Ecosystems, 1, 143-156.

HALÁS, M. (2008). Priestorová polarizácia spoločnosti s detailným pohl'adom na periférne regióny Slovenska. Sociologický časopis/ Czech Sociological Review, 44, 349-369.

HANUŠIN, J., ŠTEFUNKOVA, D. (2015). Zmeny diverzity vinohradníckej krajiny v zázemí Svätého Jura v období 1896-2011. Geografický časopis, 67, 243-259.

HORVÁTH, P. (1980). Historický prehl'ad vzniku a rozvoja chotárnych sídiel v slovenskej časti Karpát. Slovenský národopis, 28, 8-18.

HREŠKO, J., PETROVIČ, F., VRÁBELOVÁ, M. (2006). Metódy priestorového hodnotenia zmien druhotnej krajinnej štruktúry v oblasti chránených území. Acta Environmentalica Universitatis Comenianae (Bratislava), 14, 15-20.

HUBA, M. (1989). O niektorých otázkach genézy a súčasného stavu kopaničiarskeho osídlenia na území Slovenskej socialistickej republiky. Geografický časopis, 41, 138-155.

HUBA, M. (1990). O perspektívach kopaničiarskeho osídlenia a kopaničiarskej krajiny na území Slovenskej republiky. Geografický časopis, 42, 113-130.

HUBA, M. (1997). Kopaničiarske osídlenie, životné prostredie a trvalo udržatel'ný spôsob existencie. Životné prostredie, 31, 61-66.

HROMÁDKA, J. (1943). V̌̌eobecný zemepis Slovenska. Slovenská vlastiveda I. Bratislava (SAVU).

IVANOVÁ, M. MICHAELI, E., BOLTIŽIAR, M., JUHAŠČÍKOVÁ, J. (2012). Analysis of landscape heterogeneity changes on the example of Hlinné, Vyšný Žipov, and Zlatník village (Eastern Slovakia) in the period of 1826-2006. Ekológia (Bratislava), 2, 269280.

JANŠÁK, Š. (1929). Príspevok k štúdiu osídlenia Slovenska. Obce a kopanice. Sborník muzeálnej slovenskej spoločnosti, 23(3-4), 93-111.

KONEČNÝ, V., LEXA, J., PLANDEROVÁ, E. (1983). Stratigrafické členenie neovulkanitov stredného Slovenska. Západné Karpaty, séria Geológia 9. Bratislava (Geologický ústav Dionýza Štúra).

LACIKA, J. (1997). Neogene palaeosurfaces in the volcanic area of Central Slovakia. Palaeosurfaces: reconstruction and palaeoenvironmental interpretation: Geological Society Special Publication, 120, 203-219.

LACIKA, J. (2000). Condition of the Neogene planation in the Western Carpathians. Revista de Geomorfologie, 2, 15-24. 
LACIKA, J. (2001). Metodika vel'komierkovej funkčnej delimitácie reliéfu pre hospodárske využitie (modelové územie Fil'akovo a okolie). In Prášek, J., ed. Současný stav geomorfologických výskumů. Sbornik referátů $z$ medzinárodního semináre konaného $v$ dnech 5. - 7. dubna 2001 v Kružberku. Ostrava (Ostravská univerzita), pp. 69-78.

LAPIN, M., FAS̆KO, P., MELO, M., ŠŤASTNÝ, P., TOMLAIN, J. (2002). Klimatické oblasti. Mapa 1: 200 000. Atlas krajiny Slovenskej republiky. Bratislava (Ministerstvo životného prostredia Slovenskej republiky, Esprit, s. r. o).

LAPIN, M. (2012). Priemery teploty vzduchu a úhrny zrážok v Hurbanove v období 1871 $2011 \mathrm{v}$ teplom polroku. Graf, [Online.] Dostupné na: http://www.milanlapin. estranky.sk/fotoalbum/klimatologicke-grafy/ [cit:6-4-2017].

LAUKO, V. (1985). Vývoj a transformácia kopaničiarskeho osídlenia Myjavskej pahorkatiny. Acta Facultatis Rerum Naturalium Universitalis Comenianae, Geographica, 25, $35-52$.

LUKNIŠ, M. (1980). Kopaničiarske osídlenie v Gemeri. Slovenský národopis, 28, 41-50.

MAGLOCKÝ, S. (2002). Potenciálna prirodzená vegetácia. Mapa 1:500 000. A tlas krajiny Slovenskej republiky. Bratislava, (Ministerstvo životného prostredia Slovenskej republiky, Esprit, s. r. o).

MARTINKA, J. (1927). Morfologické typy slovenských osád. Sborník muzeálnej slovenskej spoločnosti, 21, 48-57.

MAZÚR, E. (1974). Využitie zeme. In Plesník, P. et al., eds. Slovensko - Lud 3, 1. čast', Bratislava (Obzor), pp. 75-100.

MAZÚR, E., LUKNIS, M. (1978). Regionálne geomorfologické členenie SSR. Geografický časopis, 30, 101-125.

Mc GARIGAL, K. (2002). Landscape pattern metrics. In El-Shaarawi, A. H., Piegorsch, W. W., eds. Encyclopedia of environmetrics, Volume 2. Chichester (Wiley), pp. 1135-1142.

NAHÁLKA, P. et al. (1966). Výskum rozptýleného osídlenia na Slovensku. Bratislava (VÚPS SSF SVŠT).

OMASTA, Š. (2011). Rozptýlené vidiecke osídlenie - socioekonomické a historické aspekty. Životné prostredie, 45, 43-47.

OŤAHEL, J., FERANEC, J., MACHKOVÁ, N. (2002). Diverzita krajiny Slovenska. Geografický časopis, 54, 131-150.

OŤAHEL, J., FERANEC, J., CEBECAUER, T., PRAVDA, J., HUSÁR, K. (2004). Krajinná štruktúra okresu Skalica: hodnotenie zmien, diverzity a stability. Geographia Slova$c a, 19$, Bratislava (Geografický ústav SAV).

PETROVIČ, F. (2005). Vývoj krajiny v oblasti štálového osídlenia Pohronského Inovca a Tribeča. Bratislava (Üstav krajinnej ekológie SAV).

PETROVIČ, F. (2006). Changes of the landscape with dispersed settlement. Ekológia (Bratislava), Supplement 1,25, 201-211.

PORUBSKÝ, A. (1982). Podzemné vody. Mapa 1:500 000. Bratislava (Geografický ústav SAV).

PRELOVSKÁ, D. (1987). Kopanice v Nitrianskej stolici v polovici 18. storočia. Agrikultú$r a, 21,41-65$.

PRIECKO, M. (2003). Spoločensko-politické zmeny po roku 1948 a ich dopad na spôsob života v kysuckých vrchárskych osadách. Národopisný zbornik, 14, 135-151.

PRIEČKO, M. (2015). Socioekonomické perspektívy rozptýleného osídlenia na Slovensku (komparácia lokalit Málinec, Nesluša a Valaská Belá). Trnava (Univerzita sv. Cyrila a Metoda).

SPIŠIAK, P. (1998). Vývoj obyvatel'stva v kopaničiarskom osídlení Slovenska. Geografické informácie, 5, 18-25.

ŠKRDLOVÁ, K. (2015). Program rozvoja obce Hrušov na roky 2015 - 2024. Vel'ký Krtíš (Centrum prvého kontaktu pre podnikatel'ov).

ŠVECOVÁ, S. (1979). Názvoslovie lazového osídlenia v Honte. Slovenský národopis, 27, 25-49. 
ŠVECOVÁ, S. (1980). Význam komasácie pre vývoj lazového osídlenia v Honte. Slo-venský národopis, 28, 35-40.

ŠVECOVÁ, S. (1984). Lazy v 19. a 20. storočí. Vývoj rol'níckych chotárnych sídiel voblasti Krupinskej planiny. Praha (Univerzita Karlova).

ŠVECOVÁ, S. (1988). Lazy a lazníci. In Botík, J., ed. Hont tradície l'udovej kultúry. Martin (Osveta), pp. 392-425.

URBÁNEK, J. (1981). Vhodnost' reliéfu pre výstavbu komunikácií. In Mazúr, E., ed. Funkčná delimitácia reliéfu pre hospodárske využitie na príklade SSR. Náuka o Zemi, geographica 4. Bratislava (Veda), pp. 65-77.

ÚGKK SR (2011). Śtatistická ročenka o pôdnom fonde v SR podl'a údajov katastra nehnutelností k 1. januáru 2011. Bratislava (Úrad geodézie, kartografie a katastra Slovenskej republiky).

VEREŚÍK, J. (1974). Vidiecka sídla. In Plesník, P. et al., eds. Slovensko - Lud 3, 1. čast'. Bratislava (Obzor), pp. 463-521.

ZRNÍKOVÁ, K., HRČKOVÁ, L. (2012). Výskum historických krajinných štruktúr a ich stupña zachovalosti pre potreby starostlivosti o krajinu vo vybraných katastrálnych územiach Hriňová a Hrušov. Krajinnoekologická štúdia. Zvolen (Technická univerzita vo Zvolene).

Mapy.cz (2012). Letecké snímky zo zdroja (C) Eurosense, [Online.] Dostupné na: https:// mapy.cz/zakladni? $\quad \mathrm{x}=19.0865350 \& \mathrm{y}=48.1651196 \& \mathrm{z}=13 \&$ source $=$ muni\&id $=\quad 20071$ [cit:6-4-2017].

Ján Ha n uš i n, Ján L a c ika

\section{SELECTED ENVIRONMENTAL CONTEXTS OF CHANGES IN THE HISTORICAL LANDSCAPE WITH A SCATTERED SETTLEMENT (THE EXAMPLE OF THE VILLAGE OF HRUŠOV, VELKÝ KRTÍŚ DISTRICT)}

Scattered settlements condition the creation of distinctive landscape structures and unique residential and building cultures. Due to its extent, it has written indelible traces on the Carpathian landscape, leaving it with its unique tangible and intangible heritage. Using the example of the cadastral territory of the Hrušov village with a scattered settlement (2331 ha, the southwestern part of the Vel'ký Krtíš district), we identified and interpreted changes in landscape cover (LC), landscape diversity (LD) and road networks in 1950 and 2010 in relation to the scattered settlement system. The LC and LD changes were identified on three spatially different levels: in the whole cadastral area, in the natural landscape units (NLUs) and in 20 circular areas. The landscape diversity was evaluated by using the Shannon Index of Diversity. The scattered settlement in Hrušov is visually and functionally similar to other scattered settlements in the surrounding region (Krupinská planina plateau), but it is different due to its genesis. Unlike most other scattered settlements that originated from "outside", i.e. with immigrants from the other regions, the Hrušov scattered settlements originated "from the inside" - they were founded by local residents.

LC categories arose from the Corine Land Cover. Afforestation and the extensification of the agricultural land use were considered, which combined the LC categories with a significant share of forest succession and non-woody vegetation (NWV) which are typical. The dense network of scattered settlements and local roads were considered too. In order to evaluate LC and LD changes at the middle level, natural landscape types (NLTs) based on morphological characteristics were set out - two types within the plain forms and 7 types within the slopes forms. There were 21 individualized NLTs identified and marked as natural landscape units (NLUs).

Based on the assumption that the surrounding area of scattered settlements were nuclei of increased LD in the 1950s, and that due to later changes, the LD in 2010 decreased here, 
we have set 20 circular areas with a radius of $200 \mathrm{~m}$ in which we studied the LC and LD changes at the lowest level. There were no changes in the LC pattern on more than half of the territory. The most distinct change in the LC layout in the rest of the territory was a significant increase of forests (by 19\%, especially in NLT in the eastern and southern parts of the territory). Arable land which decreased by $13 \%$, recorded the most remarkable opposite trend, especially in NLT isolated elevations in the central and southern parts of the territory. The scattered settlement built up areas (including home gardens) increased by about $24 \%$. In most parts of the territory an increase in LD in the year 2010 compared to 1950 has been identified. An opposite trend was recorded only on some $12 \%$ of the area. The cause was, in particular, the decrease of scattered forest and NWV enclaves and their clustering into more compact forest units. Changes in LC and LD have a different character in particular NLTs. In scattered settlement surrounding areas (within circular areas) there was a considerable extensification of agricultural production documented by a decline of the arable land and an increase of areas with forest and NWV succession. These processes were more intense there than in the rest of the territory. Our assumption on scattered settlements as a nuclei of increased LD in 1950 has not been confirmed in the analysed set of circular areas. The local road network has not undergone a major transformation over the past decades, preserving roughly the same pattern, but its quality (character of surface) has markedly changed.

The scattered settlements system, by its origin and unique functioning in Slovakia, conditioned some anomalies in LC development which are typical for marginal regions and/or areas with scattered settlements - delayed, incomplete or with no collectivization of agriculture. On the other hand, the retreat and partial extinction of scattered settlements resulted in changes in LC, whose intensity exceeded the values typical in the wider region (in particular, arable land abandonment - agricultural extensification and afforestation). The analyses of LC and LD changes belong to the standard tools of landscape assessment, enabling, among other benefits, to identify changes in the natural landscape and human activities, to define their intensity and scope, and, on the basis of such findings, to propose the elimination or mitigation of negative phenomena and processes, or vice-versa their reinforcement. 
